Dialectologia 24 (2020), 205-220.

ISSN: 2013-2247

Received 8 February 2018.

Accepted 30 June 2018.

\title{
INVESTIGATING THE FAITHFULNESS REQUIREMENT OF ROOTS: EVIDENCE FROM MALAY DIALECTS
}

\author{
Sharifah Raihan SYED JAAFAR \\ National University of Malaysia * \\ raihansyedjaafar@yahoo.co.uk
}

\begin{abstract}
It has been claimed in literature that segments at root-internal are more resistant to phonological processes than segments at other positions of words. According to Pater (1999), nasal substitution in Indonesian language is not realised within the morphemes even though there is a sequence of nasal and voiceless obstruent, for example, the word /empat/ is realised as [əmpat]. However, the occurrence of the sequence across morphemes for instance, at prefix-root boundaries is resolved by nasal substitution. For example, /məク+pukul/ is realised as [məmukul]. In this paper, the resistance of root-internal segments to phonological processes is questioned. Evidences from two Malay dialects i.e. Kelantan and Negeri Sembilan show that root-internal segments are not exempted from undergoing some phonological processes to eliminate nasal and voiceless obstruent clusters. For instance, roots like /bantal/ and /dzəmput/ are realised as [bata:] and [dzaput] in Kelantan and Negeri Sembilan dialects respectively.
\end{abstract}

\section{Keywords}

Malay dialects, nasal and voiceless obstruent clusters, root faithfulness, OT

\footnotetext{
* Linguistics Programme, School of Language Studies and Linguistics, Faculty of Social Sciences and Humanities, National University of Malaysia, 43600 Bangi, Malaysia.
} 


\section{INVESTIGANDO EL REQUISITO DE FIDELIDAD DE LAS RAICES:} EVIDENCIA DE LOS DIALECTOS DEL MALAYO

\section{Resumen}

La bibliografía afirma que los segmentos en la raíz interna son más resistentes a los procesos fonológicos que los segmentos en otras posiciones de las palabras. Según Pater (1999), la sustitución nasal en el idioma indonesio no se realiza en de los morfemas a pesar de que hay una secuencia de obstruente nasal y sorda, por ejemplo, la palabra /empat/ se realiza como [əmpat]. Sin embargo, la aparición de la secuencia a través de morfemas, por ejemplo, en los límites de la raíz del prefijo se resuelve por la sustitución de la nasal. Por ejemplo, /məわ+pukul/ se realiza como [məmukul]. En este artículo, se cuestiona la resistencia de los segmentos internos de la raíz a los procesos fonológicos. Las evidencias de dos dialectos malayos, es decir, Kelantan y Negeri Sembilan, muestran que los segmentos internos de la raíz no están exentos de someterse a algunos procesos fonológicos para eliminar los grupos obstruentes nasales y sordos. Por ejemplo, las raíces como /bantal/ y /dzəmput/ se realizan como [bata:] y [dzaput] en los dialectos Kelantan y Negeri Sembilan, respectivamente.

\section{Palabras clave}

dialectos malayos, grupos de obstruente nasal sorda, fidelidad de la raíz, teoría de la optimidad

\section{Introduction}

It has been claimed in previous studies (e.g.: McCarthy \& Prince 1995 and Pater 1999) that some phonological processes or rules are prevented from applying to rootinternal segments. In contrast, segments in other positions are not strictly blocked from undergoing the phonological processes. This restriction is due to the faithfulness requirements enforced at root-internal segments.

In view of the issue mentioned above, this paper intends to investigate the faithfulness requirements of root-internal segments. By focusing on two Malay dialects namely Kelantan and Negeri Sembilan, this paper argues that not all root-internal segments are resistant to phonological processes. This means that segments at rootmorphemes could also undergo some phonological processes like other segments at non- 
root morphemes. In the following section, some insights on past studies concerning the restrictions imposed on root-internal segments will be provided.

\section{Literature background}

It has been shown in literature that faithfulness of root-internal segments has received formal attention from scholars since a few decades ago. Some of the earliest studies were carried out by Mascaró (1976), Kiparsky (1982, 1993), McCarthy \& Prince (1995), Pater (1999) and others. These studies revealed that root-internal segments are resistance to phonological processes. However, a different scenario applies to segments at non-root morphemes like affixes whereby segments in this position are not strictly enforced from undergoing phonological processes. In other words, non-root segments are not strictly required to be as faithful as root-internal segments.

Two views have been examined namely from the perspectives of morphology and phonology in discussing this issue. The morphological point of view addresses this issue as the effect of derived environment. It is claimed that these are processes that could only be applied outside the morphemes or across morpheme boundaries, but not within a morpheme. Because of this, roots or underived words are claimed to be more resistant to phonological processes or rules than derived words such as affixes (Mascaró 1976; Kiparsky 1982, 1993). It is typical cross-linguistically that underived words do not necessary conform to some of the phonological systems in the language. In discussing word minimality, underived words are claimed not to be subject to the same minimality condition of the language (Downing 2006). Unlike underived words, derived words must obey the word minimality condition of the language. This means that underived words in a disyllabic language could appear as monosyllabic words, whereas, derived words could not. Below are some of the examples: 
Nasal fusion in Javanese (Uhrbach 1987: 233, cited in Downing 2006: 102):

(1) Disyllabic roots

$\begin{array}{ll}\text { cukur } & \text { nukur 'shave someone' } \\ \text { bali } & \text { mbaleni 'return something' } \\ \text { tulis } & \text { nulis 'to write' } \\ \text { dudut } & \text { ndudut 'pull/interesting' } \\ \text { sapu } & \text { napu 'broom/to sweep }\end{array}$

(2) Monosyllabic roots

$\begin{array}{ll}\text { cet } & \text { nəcet 'to print' } \\ \text { bom } & \text { nəbom 'to bomb' } \\ \text { Dol } & \text { nədol 'to sell' } \\ \text { Tik } & \text { nətik 'to type/typewrite' } \\ \text { Bis } & \text { nəbis '(to ride the) bus' }\end{array}$

Whereas, in phonology, this issue is regarded as the faithfulness requirement that applies to segments within the roots. According to McCarthy \& Prince (1994) and Urbanczyk (1996) show that a large number of disparate phenomena, reduplicative and otherwise, result from stricter faithfulness requirements within the roots than elsewhere in the words. This situation can be observed in Indonesian nasal substitution. It is worth mentioning that a sequence of nasal and voiceless obstruent is not allowed in the language, but they emerge in the surface representation within the roots. Nasal substitutions are generally utilised in Indonesian to eliminate nasal and voiceless obstruent clusters at prefix junctures is blocked at the internal level. The consequence of blocking nasal substitution in Indonesian results in a sequence of homorganic nasal and voiceless obstruents in the surface representation, as exemplified below:

(3) Root-internal occurrences of NÇ in Indonesian (from Pater 1999: 75; 2001)

$\begin{array}{lll}\text { /əmpat/ } & \text { [əmpat] } & \text { 'four' } \\ \text { /untuk/ } & \text { [untuk] } & \text { 'for' } \\ \text { /munkin/ } & \text { [munkin] } & \text { 'maybe' }\end{array}$


The case is different if the cluster occurs between a root and prefix, or at prefix-root juncture. In this morphological environment, nasal substitution is applied instead, as shown in the following examples:

(4) Nasal substitution in Indonesian, Chamorro and Javanese (from Pater 1999)

$$
\begin{array}{ll}
/ \mathrm{məN}+\text { sapu/ } & \text { [mənapu] 'to sweep' - Indonesian. } \\
/ \text { man+saga/ } & \text { [managa] 'to stay' - Chamorro. (Topping 1973: 50) } \\
/ \mathrm{N}+\text { sambuy/ } & \text { [nambun] 'to connect' - Javanese. (Poedjosoedarmo 1982: 51) }
\end{array}
$$

McCarthy \& Prince (1994) claimed that the lacked of nasal substitution within the roots as occurred in Indonesian is caused by the needs to maintain more contrasts between the roots and the affixes. Since the faithfulness requirement is enforced stricter to segments within the roots, therefore nasal substitution fails to apply. To explain this situation, McCarthy \& Prince (1994) proposed a general ranking schema where rootspecific versions of faithfulness constraints were ranked higher than the general version of these constraints: Root-Faithfulness >> Faithfulness. In this case, a root-specific faithfulness constraint i.e. ROOT-LINEARITY is ranked above the general faithfulness constraint i.e. LINEARITY, as shown in Tableau 1 below:

\begin{tabular}{|l||c|c|c|}
\hline$/ \partial \mathrm{m}_{1} \mathrm{p}_{2}$ at/ & LINEARITY-ROOT & *NC & LINEARITY \\
\hline \hline a. $ə \mathrm{~m}_{12}$ at & $* !$ & & $*$ \\
\hline b. $\circledast 2 \mathrm{~m}_{1} \mathrm{p}_{2}$ at & & $*$ & \\
\hline
\end{tabular}

Tableau 1. LINEARITY-ROOT >> LINEARITY.

In his analysis, Pater (2001) also discussed nasal substitution in Indonesian. Unlike McCarthy \& Prince (1994), he employed a root-specific faithfulness constraint named UNIFORMITY-ROOT to describe the faithfulness of the two segments. In his analysis, Pater showed that UNIFORMITY-ROOT blocked the sequence of nasal plus voiceless obstruent in root-internal position from undergoing nasal substitution by positioning the constraint above UNIFORMITY, the general faithfulness constraint. By using the same ranking, Pater 
also demonstrated that UNIFORMITY-ROOT which required the output to be as faithful as the input could not stop the cluster at prefix boundaries from undergoing nasal substitution. The discussion of this phonological process is summarized in Tableaux 2 and 3 below:

\begin{tabular}{|l||c|c|c|}
\hline$/ \partial \mathrm{m}_{1} \mathrm{p}_{2}$ at/ & UNIFORMITY-ROOT & ${ }^{*}$ NC & UNIFORMITY \\
\hline \hline a. $ә \mathrm{~m}_{12}$ at & $* !$ & & \\
\hline b. $2 \partial \mathrm{m}_{1} \mathrm{p}_{2}$ at & & $*$ & $*$ \\
\hline
\end{tabular}

Tableau 2. Nasal substitution is blocked root-internally in Indonesian (Pater 2001: 162).

\begin{tabular}{|l|l|l|c|}
\hline$/ \mathrm{m}_{1} \mathrm{p}_{2}$ aksa/ & UNIFORMITY-ROOT & ${ }^{*}$ NC & UNIFORMITY \\
\hline \hline a. məm $_{12}$ aksa & & & $*$ \\
\hline b. məm $_{1} p_{2}$ aksa & & $* !$ & \\
\hline
\end{tabular}

Tableau 3. Nasal substitution is unblocked at prefix boundaries in Indonesian (Pater 2001: 161).

The above literature clearly explains the occurrence of nasal substitution which is applied to nasal plus voiceless obstruent clusters is blocked root-internally. In morphology, this situation occurred due to the derived environment which only permits nasal substitution to occur across morpheme boundaries, but not within a morpheme. Based on the Optimality Theory in phonology, this phenomenon is described as a highranked root-specific faithfulness constraint in the ranking rather than a general faithfulness constraint.

\section{Data and methods}

In analysing the issue raised above, two types of data are used: (1) secondary data from previous studies and (2) interviews. Data from two previous studies namely, Che Kob (1985) and Rufus (1966) which examined Kelantan and Negeri Sembilan dialects respectively were used. Data from each study were used to examine the faithfulness of root-internal segments. Since the data from these previous studies (e.g.: Che Kob 1985; 
Rufus 1966) were inadequate to explain the issue raised in this study, interview sessions were carried out to supplement the needed information. To obtain more data, two native speakers of each dialect were interviewed. A short word list which contains nasal and voiceless obstruent clusters was prepared. ${ }^{1}$ In the interview sessions, the native speakers were asked to pronounce the words in the word list.

\section{Discussion}

As discussed in section 2, it is clear that segments in a morpheme are more resistant to phonological process like nasal substitution than segments at prefix boundaries. This shows that roots are more faithful than prefixes. Moreover, the faithfulness requirement imposed on roots as claimed by previous scholars demonstrates the contrast between roots and affixes. Given that roots are required to be faithful to its inputs rigidly than affixes do, they are more distinct.

Previous studies concerning nasal substitution suggest that the phonological process only applies to nasal plus voiceless obstruent clusters at prefix boundaries. However, it fails to apply within the roots. To demonstrate, the Indonesian nasal substitution is used as an example. As discussed in the previous section, nasal plus voiceless obstruent clusters at prefix boundaries in Indonesian are avoided by employing nasal substitution. The occurrence of the clusters, however, is permitted root-internally. As in Indonesian, the same phonological situation can be observed in standard Malay (hereafter, SM) where the clusters in the language are only banned at prefix boundaries, but not within the roots (Syed Jaafar 2011). Some examples obtained from the Malay language are illustrated below:

\footnotetext{
${ }^{1}$ Some of the word listed can be found in (7).
} 
(5) Nasal plus voiceless obstruent clusters root-internally in SM (Syed Jaafar 2011)

$\begin{array}{ll}\text { Input } & \text { SM } \\ \text { /kampun/ 'village' } & \text { [kampon] } \\ \text { /sampan/ 'small boat' } & \text { [sampan] } \\ \text { /lompat/ 'to jump' } & \text { [lompat] } \\ \text { /pintu/ 'door' } & \text { [pintu] } \\ \text { /tempat/ 'place' } & \text { [tempat] } \\ \text { /tankap/ 'to catch' } & \text { [tankap] } \\ \text { /hantu/ 'ghost' } & \text { [hantu] }\end{array}$

(6) Nasal plus voiceless obstruent clusters at prefix boundaries in SM (Syed Jaafar 2013)

/mən-kuat-kan/ [mə-nuwat-kan]

ACT.PRF-strong-CAUS.SUF 'to cause to strengthen for' /pəy-pindah-an/ [pə-mindah-an] NOM.PRF-migrate-NOM.SUF 'migration' /mən-kunjun-i/ [mə-nundzung-i]

ACT.PRF-visit-LOC.SUF 'to cause to visit'

The evidences from Indonesian and SM support the claim made by previous studies concerning roots faithfulness requirement. It is important to highlight that the roots faithfulness requirement is somehow violated. The relation between the segments in the input and the output are not fully obeyed in some of the Malay dialects. Based on the two dialects of Malay i.e. Kelantan and Negeri Sembilan, this paper claims that nasal plus voiceless obstruent clusters in root-internally could also undergo a phonological process. This is evident based on the data obtained from the previous studies and the interviews as shown below:

(7) Nasal and voiceless obstruent root-internally in Kelantan and Negeri Sembilan dialects

\begin{tabular}{|c|c|c|c|}
\hline Input & SM & Kelantan & Negeri Sembilan \\
\hline kampun 'village' & kampon & kapon & kapon \\
\hline sampan 'small boat' & sampan & sap $\tilde{\varepsilon}$ & sapan \\
\hline sampai 'arrive' & sampai & sape & sapa \\
\hline
\end{tabular}




\begin{tabular}{|c|c|c|c|}
\hline kuntum 'flower' bud' & kuntom & kutum & kutom \\
\hline $\begin{array}{l}\text { Kelantan 'the name of } \\
\text { a state' }\end{array}$ & kəlantan & kəlat $\tilde{\varepsilon}$ & kəlatan \\
\hline tenkat 'level' & tenkat & teka? & teka? \\
\hline təmpat 'place' & təmpat & tәра? & tәра \\
\hline tampar 'to slap' & tampar & tapa: & tapo \\
\hline bantal 'pillow' & bantal & bata: & bata \\
\hline sampul 'envelope' & sampol & sapo & sapo \\
\hline dzəmput 'invite' & dzəmpot & dзәро? & dzaput \\
\hline gantun 'hang' & ganton & gaton & gaton \\
\hline pintu 'door' & pintu & Pitu & pitu \\
\hline simpan 'keep' & simpan & $\operatorname{sip} \tilde{\varepsilon}$ & sipan \\
\hline tonkat 'stick' & tonkat & toka? & toka? \\
\hline səmpit 'narrow' & səmpit & səpe? & sope? \\
\hline tankap 'to catch' & tankap & taka? & taka? \\
\hline guntin 'scissor' & gunten & gutin & guten \\
\hline sampah 'rubbish' & sampah & sapoh & sapah \\
\hline hancin 'foul-smelling' & hancen & hacin & acen \\
\hline pantan 'prohibition' & pantan & patan & patan \\
\hline təntu 'sure' & təntu & tətu & tətu \\
\hline pantai 'beach' & pantai & pat $\varepsilon$ & patay \\
\hline Puntun 'profit' & Punton & Puton & Puton \\
\hline tankat 'hillock' & tankat & caka? & caka? \\
\hline
\end{tabular}

The above data indicates that root-internal segments are not resistant to phonological processes as claimed before, whereby nasal segments which precede voiceless obstruents undergo deletion. Nasal and voiceless obstruent clusters rootinternally are not manifested phonetically in Kelantan and Negeri Sembilan dialects. Based on the data shown above, it is questionable whether root-internal segments are completely blocked from undergoing any phonological processes and whether they are more faithful than segments in other positions? In view of this data, this paper argues that faithfulness requirement enforces to the segments in roots is not applicable to all 
root-internal segments. In other words, root-internal segments are not fully resistant to phonological processes because of the occurrence of nasal deletion. The process of nasal deletion can be illustrated in the following schematic diagram.

(8) Correspondence diagram for nasal deletion (Kager 1999)

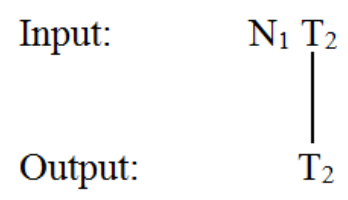

Since nasal deletion is applied to avoid a sequence of nasal plus voiceless obstruent within the roots in Kelantan and Negeri Sembilan dialects, therefore, the root-internal faithfulness requirement is not crucial as it could not always be met. The application of nasal deletion means that faithfulness requirement is not completely obeyed by the segments inside the roots. Given this scenario, this paper claims that markedness requirement is more crucial than faithfulness requirement in handling nasal and voiceless obstruent clusters. It could be predicted that the outputs derived would be unmarked segments i.e. no nasal plus voiceless obstruent clusters since markedness requirement is highly required in the grammar. This also means that the grammars of those dialects still prefer the unmarked segments over the marked segments. In OT, this situation could be explained in terms of constraint interaction i.e. faithfulness to the segments in roots is completely dominated by markedness constraint, as shown below:

(9) Nasal and voiceless obstruent clusters

$$
\begin{aligned}
& \text { Markedness } \gg>\text { Root-faithfulness } \\
& { }^{*} \text { NC } \gg \text { UNIFORMITY-ROOT }
\end{aligned}
$$

Given the above interaction of constraint ranking, the grammar is less faithful to its input segments. It blocks the surfacing of any nasal plus voiceless obstruent clusters since the markedness constraint, *NC outranks the faithfulness constraint, UNIFORMITY-ROOT. The application of nasal deletion as in those two dialects of Malay clearly shows that the 
outputs without nasal plus voiceless obstruent clusters are more desired than the one that demonstrates the expected behaviour. This means that outputs which produce unmarked forms are the correct grammatical form in those dialects.

As discussed beforehand, the situation occurred in the two Malay dialects, shows that they involved unmarked and marked segments. Since the phonological requirement does not allow voiceless obstruent to be followed by a nasal segment, thus the unmarked value for the segmental feature [voice] is [+voice]. This means that the obstruent follows the nasal segment must be a voiced obstruent. Any unvoiced obstruent after the nasal segment would violate the markedness constraint, *NC.. Besides, having an unvoiced the obstruent, means that there are other conditions need to be observed in ensuring that the markedness constraint is respected. For example, by not having the clusters, either the nasal segment or the unvoiced obstruent is deleted, inserting a vowel between the clusters or they could merge into one segment. The deletion, insertion and merging processes however would not observe MAX-IO, DEP-IO and UNIFORMITY-ROOT constraints, respectively.

(10) *NC

No nasal/ voiceless obstruent sequences.

(11) MAX-IO (MAXIMAL INPUT-OUTPUT)

Every segment in the input must have a correspondent in the output.

(12) DEP-IO (DEPENDENCE INPUT-OUTPUT)

Every segment in the input must have a correspondent in the output.

(13) UNIFORMITY-ROOT

The output reflects the precedence structure of the input segments of the roots, and vice versa.

Since the data obtained are insufficient, the OT analysis in this paper will follow the schematic account employed by Kager (1999). In the process of nasal deletion, an input 
with a sequence of nasal $\left(\mathrm{N}_{1}\right)$ and voiceless obstruent $\left(\mathrm{T}_{2}\right)$ are mapped onto a single output segment that is $T_{2}$, thus, the nasal segment precedes the voiceless obstruent in the input which is deleted.

The interaction of the constraints mentioned above is shown in Tableau 4. Those four constraints are ranked accordingly as follows:

DEP-IO $\gg$ *NC $\gg>$ UNIFORMITYROOT $\gg$ MAX-IO

\begin{tabular}{|l||c|c|c|c|}
\hline Input: $/ \mathrm{N}_{1} \mathrm{~T}_{2} /$ & DEP-IO & *NC & UNI ROOT & MAX IO \\
\hline \hline a. $\mathrm{T}_{2}$ & & & & $*$ \\
\hline b. $\mathrm{N}_{12}$ & & & $* !$ & \\
\hline c. $\mathrm{N}_{1} \partial \mathrm{T}_{2}$ & $* !$ & & & \\
\hline d. $\mathrm{N}_{1} \mathrm{~T}_{2}$ & & $* !$ & & \\
\hline
\end{tabular}

Tableau 4. Nasal deletion in the Kelantan dialect.

The above tableau briefly demonstrates the constraint ranking to account for NT sequence. As shown candidate (c) with schwa epenthesis fatally violates DEP-IO. In view of the markedness constraint, ${ }^{*} \mathrm{NC}$ is highly ranked in the ranking than the faithfulness constraint, UNIFORMITYROOT, hence candidate (d) with a sequence of nasal and voiceless obstruent is ruled out. In contrast, candidate (b) who respects the markedness constraint *NÇ, violates UNIFORMITYROOT. Candidate (a) with nasal deletion emerges as the one with optimal output although the segmental faithfulness does not longer hold. This is because the voiceless obstruent $[t]$ in the candidate does not precede by a nasal segment anymore. It therefore respects *NC..

As presented in (7), nasal and voiceless obstruent sequences in the two dialects are treated differently from the standard version of Malay, SM. The sequence of the consonants in SM is retained in the words, therefore no nasal deletion takes place. The following tableau shows the constraint ranking for SM which is distinct from the one demonstrated in Tableau 4. 
DEP-IO > UNIFORMITYROOT > MAX-IO > *NC

\begin{tabular}{|l||c|c|c|c|}
\hline Input: $/ \mathrm{N}_{1} \mathrm{~T}_{2} /$ & DEP-IO & UNI & MAX IO & $*$ NCC \\
\hline \hline a. $\mathrm{T}_{2}$ & & & $* !$ & \\
\hline b. $\mathrm{N}_{12}$ & $* !$ & & & \\
\hline c. $\mathrm{N}_{1} \partial \mathrm{T}_{2}$ & & & & $*$ \\
\hline d. $\mathrm{N}_{1} \mathrm{~T}_{2}$ & & & & \\
\hline
\end{tabular}

Tableau 5. A sequence of nasal and voiceless obstruent in SM.

The constraint ranking for SM above differs slightly from the non-standard dialects of Malay. As can be seen in candidate (d) above, a sequence of nasal and voiceless obstruent is retained, hence the faithfulness constraint that preserves root segments named UNIFORMITY-ROOT should dominate the markedness constraint *NCূ: [F >> M], not the opposite way as for the dialect. This shows that the same markedness constraint which is active in the Malay language grammar has been satisfied differently. According to McCarthy (2002), the same markedness constraint with different satisfaction is called homogeneity of target/heterogeneity of process. In phonology, the same target is achieved by different ways in different languages. For example, certain consonant clusters are avoided in different ways like deletion as in Diola Fogny and vowel epenthesis as in Ponapean (McCarthy 2002: 26). Apart from different languages, homogeneity of target/heterogeneity of process can also be observed within a single language. Vowel denasalisation in Nancowry is an instance for this, whereby this process is defined by the ranking $* \mathrm{~V}_{\mathrm{NAS}} \gg$ IDENT(nasal). Vowel denasalisation however is blocked in stressed syllables by ranking IDENT(nasal) higher than * $\mathrm{V}_{\text {NAS }}$ (McCarthy 2002: 95).

The discussion of nasal and voiceless obstruent sequences in the Malay language indicates that the homogeneity of target/heterogeneity of process occurs in the language. The optimal output in the language i.e. no nasal and voiceless obstruent sequences is evident that the Malay language needs to be accomplished by the markedness constraint *NC must dominate the root-faithfulness constraint, UNIFORMITY-ROOT: *NC >> 
UNIFORMITY-ROOT. Referring to tableau 4, in cases where F1 (UNIFORMITY-ROOT) and F2 (MAX-IO) are dominated by $M\left({ }^{*} N C\right)$, the output is therefore unfaithful. When both F1 and F2 dominate $M$, then the mapping is faithful, as shown in Tableau 5.

(14) Permuted rankings for *NC
a. *NC $\gg$ UNIFORMITY-ROOT $\gg$ MAX-IO
b. UNIFORMITY-ROOT $>>$ MAX-IO $>$ *NC

The different ways of treating nasal and voiceless obstruent sequences in Malay language could be well-explained in OT by the homogeneity of target/heterogeneity process. The case would be difficult to explain when rule-based theories take place since phonological processes in SPE are expressed by rules.

\section{Conclusion and prediction}

Based on the discussion, it can be summarised that the form of the output which contains a sequence of nasal plus voiceless obstruent depends on the ranking of faithfulness constraint with respect to the markedness constraint. To achieve the target that the Malay language needs, M i.e. *NC needs to be accomplished in different ways, even within a single language. In view of the homogeneity of target/heterogeneity of process, the discussion shows that the target of the language could not always be achieved. With respect to the unmarked segments, the following constraint ranking has been established: DEP-IO > * NC $>$ > UNIFORMITYROOT > MAX-IO. The data also reveal that Kelantan and Negeri Sembilan dialects still favour the unmarked segments rather than marked segments. As a consequence, the root-faithfulness requirement is no longer obeyed in those dialects. 


\section{References}

CHE KoB, Ajid (1985) Dialek Geografi Pasir Mas, Bangi: The Publisher of National University of Malaysia.

DoWNING, Laura (2006) Canonical Forms in Prosodic Morphology, Oxford: Oxford University Press. KAGER, René (1999) Optimality theory, Cambridge: Cambridge University Press.

KIPARSKY, Paul (1982) "From cyclic phonology to lexical phonology", in H. van der Hulst \& N. Smith (eds.), The structure of phonological representations, part 2, Dordrecht: Foris 131-176.

KIPARSKY, Paul (1993) "Variable rules", Handout distributed at the Rutgers Optimality Workshop (ROW1).

MASCARÓ, Joan (1976) Catalan phonology and the phonological cycle, PhD thesis, MIT Distributed by Indiana Linguistics Club.

McCarthy, John J. 2002. A thematic guide to Optimality theory. Cambridge: Cambridge University Press.

MCCARThY, John J. \& Alan S. PRINCE (1994) "The emergence of the unmarked: Optimality in prosodic morphology", Proceedings of the North East Linguistic Society, 24, 333-379.

MCCARTHY, John J. \& Alan S. PRINCE (1995) Faithfulness and reduplicative identity. University of Massachusetts Occasional Papers in Linguistics 18: Papers in Optimality Theory. [Available in ROA-60 <http://ruccs.rutgers.edu/roa.html>

PATER, Joe (1999) Austronesian nasal substitution and other NC effects, in René Kager, Harry Van Der Hulst \& Wim Zonneveld (eds.), The prosody-morphology interface, Cambridge: Cambridge University Press, 310-343.

PATER, Joe (2001) "Austronesian nasal substitution revisited", in Linda Lombardi (ed.), Segmental phonology in Optimality theory: constraints and representations, Cambridge: Cambridge University Press, 159-82.

POEDJOSOEDARMO, Soepomo (1982) Javanese influence on Indonesian, Canberra: Pacific Linguistics D 38.

Rufus, Hendon (1966) The Phonology and Morphology of Ulu Muar Malay. Yale Publication in Anthropology, 70, Yale University.

SYED JAAFAR, Sharifah Raihan (2011) Prefixation and Reduplication in Malay: An Optimality Theoretic Account, Ph.D. Dissertation, Lancaster University. 
SYed JAAFAR, Sharifah Raihan (2013) Is Malay Grammar Uniform? A Constraint-Based Analysis, Formal Grammar 2012/2013, LNCS 8036, 109-125.

TOPPING, Donald M. (1973) Chamorro reference grammar, Honolulu: University of Hawaii Press.

UHRBACH, Amy (1987) A formal analysis of reduplication and its interaction with phonological and morphological processes, Ph.D. dissertation. University of Texas. 